\title{
Multiple shallow level sill intrusions coupled with hydromagmatic explosive eruptions marked the initial phase of Ferrar large igneous province magmatism in northern Victoria Land, Antarctica
}

\author{
L. Viereck-Goette, ${ }^{1}$ R. Schöner, ${ }^{1}$ B. Bomfleur, ${ }^{2}$ and J. Schneider ${ }^{3}$ \\ ${ }^{1}$ Friedrich-Schiller-Universität Jena, Institut für Geowissenschaften, Burgweg 11, 07749 Jena, Germany (lothar.viereck-Goette@uni-jena.de ; \\ robert.schoener@uni-jena.de) \\ ${ }^{2}$ Westfälische Wilhelms-Universität Münster, Geologisch-Paläontologisches Institut, Hindenburgplatz 57, 48143 Münster, Germany \\ (bennibomfleur@gmx.de ; kerp@uni-muenster.de) \\ ${ }^{3}$ TU Bergakademie Freiberg, Institut für Geologie, Bernhard-von-Cotta Str. 2, 09596 Freiberg, Germany (schneidj@ geo.tu-freiberg.de)
}

\begin{abstract}
Field data gathered during GANOVEX IX (2005/2006) in Northern Victoria Land, Antarctica, indicate that volcaniclastic deposits of phreatomagmatic eruptions (so-called Exposure Hill Type events) are intercalated with fluvial deposits of Triassic-Jurassic age at two stratigraphic levels. Abundant scoriaceous spatter (locally welded) indicates a hawaiian/strombolian component. Breccia-filled diatremes, from which volcaniclastic deposits were sourced, are rooted in sills which intruded wet sediments. The deposits are thus subaerial expressions of initial Ferrar magmatism involving intrusion of multiple shallow-level sills. Due to magma-sediment interaction abundant clastic dikes are developed that intrude the sediments and sills. All igneous components in the volcaniclastic deposits are andesitic in composition, as are the chilled margins of the sills. They are more differentiated than the basaltic andesites of the younger effusive section of Kirkpatrick plateau lavas which in northern Victoria Land start with pillow lavas and small volume lava flows from volcanic necks.

Citation: Viereck-Goette, L., R. Schöner, B. Bomfleur and J. Schneider (2007), Multiple shallow level sill intrusions coupled with hydromagmatic explosive eruptions marked the initial phase of Ferrar Magmatism in northern Victoria Land, Antarctica, in Antarctica: A Keystone in a Changing World - Online Proceedings of the 10th ISAES, edited by A.K. Cooper and C.R. Raymond et al., USGS Open-File Report 2007-1047, Short Research Paper 104, 5 p.; doi:10.3133/of2007-1047.srp104
\end{abstract}

\section{Introduction}

The Ferrar large igneous province (FLIP) in Antarctica is one of the large mafic igneous provinces related to the break-up of Gondwana. Thick (up to 1000 m) basaltic andesitic Kirkpatrick Basalt lava flows occurring from North Victoria Land (NVL) to the Central Transantarctic Mountains (CTM) and rarely underlain by epiclastic and volcaniclastic sediments. These are intruded by widespread massive sills, several hundred meters in cumulative thickness that exhibit in-situ differentiation. The field relations between igneous and sedimentary rocks provide information on the initiation of magmatic activity in the FLIP that may be generalized to this province as a whole. From previous investigations it was inferred that in NVL continuous sections of clastic strata pre-dating the Kirkpatrick lava flows could be exposed in the Deep Freeze Range (Elliot et al., 1986; Elliot, 2000; Roland and Wörner, 1996).

As a complementary paper to that of Schöner et al. (2007, this volume) we herein describe the field relations, petrography and geochemistry of components within volcaniclastic rocks of the "Exposure Hill Formation" and of the intrusive and extrusive igneous rocks they are associated with.

\section{Field observations}

Field investigations during the 9th German Antarctic North Victoria Land Expedition (GANOVEX IX, 2005/06) resulted in the revision of the Triassic-Jurassic stratigraphy in southern North Victoria Land (Schöner et al. 2007, this volume), which is briefly summarized within this chapter.

\section{Stratigraphy}

The stratigraphically lowermost unit about $200 \mathrm{~m}$ thick, termed the Section Peak Formation (SPF), is dominated by medium- to coarse-grained, trough crossbedded quartz sandstones; a Dicroidium-flora suggests a Late Triassic age. It overlies the erosion surface cut across Ross orogenic metamorphic and igneous basement of Early Paleozoic age.

A newly identified, stratigraphically higher, unit of about $50 \mathrm{~m}$ thickness, informally called Shafer Peak Formation (SHF), is dominated by fine-grained, ripple cross-laminated tuffaceous sandstones and siltstones, consisting dominantly of silicic shards; an Early Jurassic age is inferred from the absence of a Dicroidium-flora and the presence of a flora of Bennettitales, Cycadophytes and Dipterid ferns. Musumeci et al. (2006) described these sedimentary rocks and included them in the Exposure Hill Formation (see below).

Intercalated at two stratigraphic levels within the SHF and uppermost SPF, and/or cutting through both sedimentary sequences (SPF and SHF) as diatremes, are volcaniclastic deposits resulting from hydrovolcanic eruptions. Contrary to all previous descriptions from NVL, SVL and CTM, these rocks do not form a single, synchronous stratigraphic horizon and thus do not form a stratigraphic "Formation". Based on the formerly introduced terminology by Elliot et al. (1986) they are rather referred to as Exposure Hill Type (EHT) "events".

Equivalent diatreme fillings have been described from South Victoria Land (SVL) and the Central Transantarctic Mountains (CTM) (Elliot and Hanson, 2001, White and 
McClintock, 2001, McClintock and White, 2006). The diatreme fillings, with exposed thicknesses of $50-200 \mathrm{~m}$, are developed as chaotic breccias or block-bearing tuffs at the base, grading into a finer grained upper part dominated by reworked volcaniclastic sandstones, which may be interbedded with fine-grained sand- to siltstones of the SHF. Often this sequence is capped by a laterally restricted black (carbonaceous) lacustrine shale. The filling may be intruded by mafic igneous bodies, e.g. at Exposure Hill, the type locality of the "Exposure Hill Formation" (Elliot et al., 1986).

Sills with well-developed columnar jointing intrude the sedimentary succession throughout the field area investigated. Their individual thickness may reach $100 \mathrm{~m}$, but they exhibit multiple subplanar jointing parallel to chilled or brecciated boundaries due to multiple intrusive phases.

Rare small dikes are less than a few meters wide and cut the Section Peak Fm. and deposits of Exposure Hilltype events. A single massive, several hundred $\mathrm{m}$ wide dike of massive basaltic andesite is exposed over some kilometers cutting all units and enclosing house-sized sediment rafts tilted vertically.

The epiclastic/volcaniclastic successions are typically covered by a pillow succession, $10-20 \mathrm{~m}$ thick, and/or small compound lava flows a few $10 \mathrm{~s}$ of $\mathrm{m}$ thick. Field observations suggest that these first effusive products are regionally restricted and derived from volcanoes such as that represented by the Mt Carson neck (cf. Figure 1 in Schöner et al. 2007, this volume). They extruded onto unconsolidated wet sediments of SHF-type, which were locally injected several meters upward into the pillow sequence. Locally they enclose in-situ standing trees. Glassy rims, a few $\mathrm{cm}$ thick, are widespread and are still preserved as isotropic, often perlitic glass. These smallvolume lavas are locally separated from the younger voluminous plateau-forming Kirkpatrick lava flows by (thin) intercalated epiclastic or volcaniclastic sediments, most often only $1 \mathrm{~m}$ in thickness.

\section{Intrastratigraphic volcaniclastics of EHT events}

The intrastratigraphic volcaniclastic rocks resulting from Exposure Hill Type (EHT) diatreme-forming hydromagmatic "events" can be divided into distal, medial and proximal facies by the thickness, sorting and layering of the sedimentary units as well as the size, form and crystallinity of juvenile and other igneous particles.

Indications of distal explosive mafic eruptions are conserved as mm-sized, (secondarily) red coloured, vesicle-poor, angular fragments or $\mathrm{cm}$-sized flat, red to dark brown, vesicular lumps with spatter morphology that occur as individual clasts or enriched in a cm-thick zone in a succession of poorly to well stratified fine grained sandstone layers of the SHF. The colour of the SHF sandstone matrix is generally beige, but may change to green with increasing abundance of lumps.
Medial facies of EHT deposits are represented by some 10-20 meter thick successions of well stratified, cmto dm-thick bedded tuffs, enriched in green to brown lapilli and white bombs of aerodynamically deformed scoriaceous spatter (Figure 1) as well as dense, crystalline, angular, mafic lapilli or blocks. The fragments may be separated based on crystallinity into (1) microcrystalline, light grey, (2) finely crystalline, greenish, gray or rusty, and (3) medium-crystalline, olivebrown (sill-type). Stratification on a $\mathrm{cm}$ to $\mathrm{dm}$ scale is indicated by variations in amount and size of lapilli and bombs/blocks; some horizons are strongly enriched in lapilli-sized scoriaceous lumps. The proportion of primary beds deposited from low-density currents is difficult to estimate. Some layers exhibit slumpingtextures, in which block/bomb- and lapilli-sized clasts of all types occur in a matrix with contorted and disrupted layering indicated by variations in amount and size of lumps. Some dm-thick layers are poorly stratified and poorly sorted, block- and lapilli-bearing tuffs, with discordant contacts, most likely formed by low to high density debris flows. They may additionally contain lapilli-sized angular, vitric, non-vesicular fragments, that are inferred to have been generated by spalling of chilled margins from sills (Figure 1).

The colour of the matrix in the sedimentary succession locally changes from green at the base to the dominantly brown colour of these successions, depending on the dominance of silicic shards of SHF origin versus quartz dominated detritus of SPF origin.

Proximal expressions of EHT events in sedimentary profiles are typically $20-30 \mathrm{~m}$, rarely $50 \mathrm{~m}$, thick successions of massive, less stratified and poorly sorted hydroclastic breccias and block-rich tuffs. Their coarse fractions are dominated by angular block-sized igneous clasts of variable crystallinity, but vesicular to collapsed bombs, a few $\mathrm{dm}$ to $5 \mathrm{~m}$ in length, are also present (Figure 1). Locally, such deposits are interbedded with layers enriched in collapsed bombs up to $>1 \mathrm{~m}$ in length, which locally form welded intervalls less than $1 \mathrm{~m}$ thick (N-end Suture Bench), indicating Hawaiian type fountaining due to expansion of magmatic volatiles and resultant magma fragmentation (cf. Hanson and Elliot 1996).

\section{Genetic link between EHT deposits and sills}

The eruptive centers that produced the EHT deposits are represented by diatremes. Their fillings of chaotic breccias and block-bearing tuffs contain igneous clasts of varied crystallinity as well as juvenile scoriaceous clasts. Whereas rafts of the two epiclastic successions (SPF and $\mathrm{SHF}$ ) are common in tbe deposits no basement clasts are present in any of the volcaniclastic sediments formed by EHT events. This indicates that the fragmentation level of the hydromagmatic eruptions was always restricted 

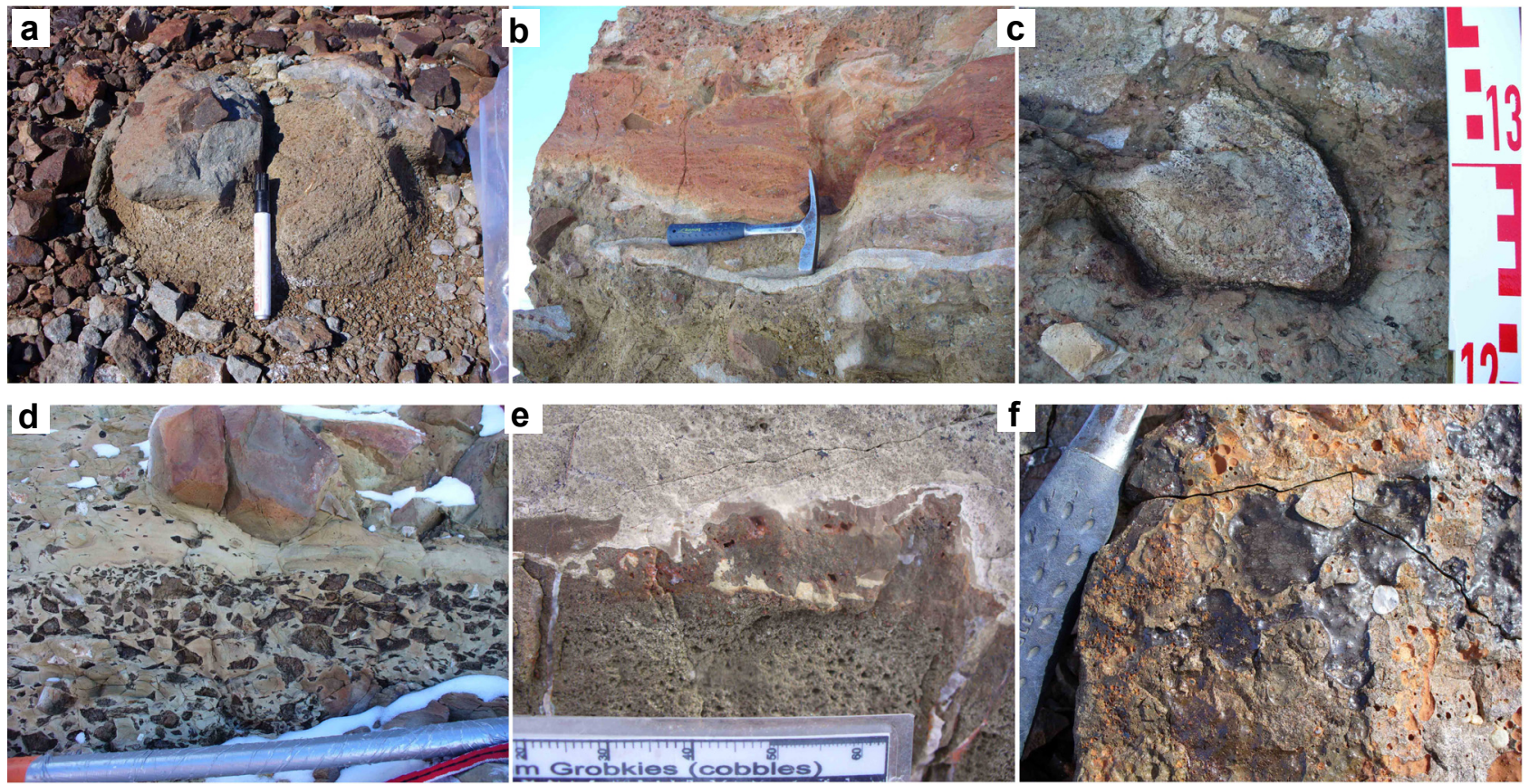

Figure 1. (a) - rim of juvenile whitish andesite enclosing block of medium-crystallinity sill, containing aphanitic, red sill fragments, Chisholm Hills N-Ridge; (b) - reddened welded whitish spatter, underlain by block-bearing tuff, Suture Bench; (c) - deformed spatter of bomb-size, Mt. Carson E-Ridge; (d) - vitric angular lapilli and aphanitic blocks in structureless matrix of SHF, intruding layered sediments of the SHF, Mt. Carson E-Ridge; (e) - almost detached vesicular lumps of sill at contact with enclosed raft of wet sediment, Mt. Carson southern N-Ridge; (f) - glassy glaze on surface of sediment-coated dike in sill, Mt. Carson E-Ridge.

to shallow depths, within the $<300 \mathrm{~m}$ thick sedimentary cover. The field observations suggest that all transitions exist from (1) diatremes, to (2) plugs extending upward from sills, decameters in size, of brecciated basalt with sediment interstices in the centre, grading outward into basalt fragments embedded in structureless sedimentary material modified from the SHF to (3) meter-sized apophyses of sills extending several meters upward into sedimentary rocks of the SHF.

\section{Sediment-magma interaction}

Due to the interaction of shallow level sill intrusions and the embedding wet sediments various types of mixed sediments occur, that are especially well exposed in the area around Mt. Carson. The products comprise mixed sediments with SHF matrix, that contain all juvenile lithologies mentioned above as being characteristic of the medial facies of intrasedimentary volcaniclastics of EHT events as lapilli and blocks. These clastic dikes intrude SHF strata (cross-cutting as well as sub-planar) as well as magmatic sills as clastic dikes. These observations are complementary to those made by Grapes et al. (1973) Korsch (1984), Ross and White (2006) in SVL and compare well with those described by Kokelaar (1982).

These clastic dikes are lithologically identical to some of the poorly stratified and sorted subaerial debris flow- deposits described above as EHT deposits in medial facies. Thus they may have had the potential to extrude, however, the uninterrupted continuation of a vertical clastic dike into a subaerial syn-stratigraphic sedimentary horizon has not been observed.

Of special relevance for the genesis of these deposits are fine-grained sandstone dikes in sills that became fused during intrusion. They follow fractures for several meters laterally and upward with a width of $0.1-15 \mathrm{~cm}$, locally split into several individual clastic dikes and reunite again. The most prominent of such dikes grade upward into "fragmented" (veined) and vesiculated sediment and terminatein a zeolite-silica-filled cavity $30 \mathrm{~cm}$ in diameter at the uppermost head. This indicates that the sediments followed a fracture induced by gas pressure (cf. McClintock and White 2006). This model may be supported by inner walls of intra-sill fractures being coated by a black glass glaze (Figure 1).

Where blocks of SHF sediments are enclosed in sills, (1) the sediment commonly lacks internal stratification; (2) it is locally injected into the sill for a few dm, and (3) large-vesicular, irregular clasts are separated from the generally small- vesicular sill basalt into the enclosed sediment (Figure 1). The latter may be due to steaminduced reduction of the magma viscosity. 




Figure 2. Variation of immobile compatible elements (left: $\mathrm{Ni}$, right: $\mathrm{Cr}$ ) using the incompatible element $\mathrm{Zr}$ as a differentiation index. Symbols: open circles - pillows and small volume flows, filled circles - chilled (glassy) margins of sills, crosses - clasts in volcaniclastic sediments of Exposure Hill Type events; open square - chilled margins of sills in Tasmania and Central Transantarctic Mountains (Hergt et al. 1989a, Hergt et al. 1989b), light grey reference field Kirkpatrick flows Mesa Range, northern Victoria Land (Elliot et al., 1995), sills and flows in northern North Victoria Land and George V Land (Hanemann and Viereck-Goette, 2004), dark grey field - sills in Eisenhower Range and Deep Freeze Range, southern North Victoria Land (Brotzu et al. 1992, Antonini et al. 1999).

\section{Initial geochemical data \\ Sills}

The sills exhibit intersertal textures normally typical of effusive flows, indicating that they are shallow level $(<$ $300 \mathrm{~m}$ ) intrusions. All units are free of olivine, the MgFe-Si phase being hypersthene. Chilled margin glass at the contact with SHF sediments is still isotropic, although locally perlitic.

The glassy margins of sills are of uniform andesitic composition with respect to major, minor and trace elements $\left(\mathrm{SiO}_{2}\right.$ 57-58 wt.\%, $\mathrm{MgO} 4$ wt. $\%, \mathrm{Cr}<60$ ppm, $\mathrm{Ni}<60 \mathrm{ppm}, \mathrm{Zr}>90 \mathrm{ppm}$ ) (Figure 2). They thus confirm the more differentiated composition of Ferrar sills in southern North Victoria Land (Eisenhower and Deep Freeze Range) (Brotzu et al., 1992, Antonini et al., 1999) within the Ferrar province (Hergt et al., 1989a, 1989b, Elliot et al., 1995, Fleming et al., 1995, Hanemann and Viereck-Goette, 2004). As do all sills analyzed in the Ferrar LIP, they belong to the low-Ti (Mt Fazio) magma type.

\section{Igneous clasts in volcaniclastics of EHT events}

The juvenile scoriaceous lumps and bombs in the volcaniclastic sediments from Exposure Hill Type events, as well as all igneous clasts of various crystallinity, are andesitic in chemical composition with respect to their contents of immobile compatible (e.g. Cr, Ni) and incompatible elements (e.g. Zr) (Figure 2). Their mineralogical and chemical compositions are indistinguishable from sill compositions. Only a few exhibit $\mathrm{Zr}$ contents above $150 \mathrm{ppm}$. The petrographic and chemical data are consistent with the observation that the diatremes are rooted in sills. Thus, all igneous clasts are comagmatic in origin. They are more differentiated than the basaltic andesites of the Kirkpatrick plateau lavas of low-Ti (Mt. Fazio) type $\left(\mathrm{SiO}_{2} 53-55\right.$ wt. $\%, \mathrm{MgO}>6$ wt.\%) that started with pillow lavas and small volume lava flows from local centres. However, major-element contents including $\mathrm{SiO}_{2}$ vary widely in altered clasts, from basaltic to dacitic compositions, reflecting the known mobility of Si during alteration of volcaniclastic deposits. Zeolites of the heulandite group, K-feldspars, calcium carbonate and Fe-chlorites, identified by microprobe analyses, form alteration products.

Clasts of primary dacitic composition as well as garnet-bearing peraluminous magmas are absent. The almandine garnets, which were described in deposits of EHF events and taken as proof of the peraluminous nature of these dacites (Roland and Woerner 1996), were most likely derived from desintegrated SPF sandstones, where garnet is a common heavy mineral.

\section{Pillow lavas}

The compositions of the glassy rims of pillow lavas and of the associated small-volume lava flows are basaltic andesitic, thus less differentiated than that of the sills as well as the clasts in volcaniclastic rocks of the EHT units (Figure 2); they are chemically indistinguishable from the Kirkpatrick flows in North Victoria Land and sills in both northern North Victoria Land and Tasmania. They are free of olivine and often contain hypersthene aside from plagioclase as phenocrysts; additional mineral phases are Ca-rich pyroxene and Ti-magnetite. Chlorites, zeolites, calcite and silica-phases are present as secondary phases.

\section{Conclusions}

Emplacement of the FLIP started with two phases of shallow-level $(<300 \mathrm{~m})$ sill-intrusions of (low-Ti type) 
andesitic magma. The diatremes and intrastratigraphic volcaniclastic rocks of Exposure Hill Type (EHT) units are the surface expression of sill intrusion into wet tuffaceous sediments of the newly identified Shafer Peak Formation (SHF), which caused significant hydroclastic magma fragmentation. Presence of scoriaceous lumps and welded spatter indicates that Hawaiian/strombolian-type explosivity also developed in these andesitic EHT magmas. EHT rocks are chemically identical to the sills but differ from the lavas of the Kirkpatrick flows. The capping pillow lava/lava flow succession is chemically comparable to the overlying Kirkpatrick lavas and may have been produced by an initial small volume eruptive phase of the subsequent plateau forming eruptions.

Acknowledgments. We are grateful to the Bundesanstalt für Geowissenschaften und Rohstoffe (BGR), Hannover, Germany, for inviting us to join the expedition GANOVEX IX, and for generous logistical support during the expedition. Prior to the field season Dave Elliot kindly provided us with information on selected outcrops in northern Victoria Land. The ongoing project is funded by the German Research Foundation (DFG), grants VI 215/6-1, SCHN 408/11-1, KE 584/12-1 and GA 457/11-1.

\section{References}

Antonini, P., E.M. Piccirillo, R. Petrini, L. Civetta, M. D'Antonio and G. Orsi (1999), Enriched mantle - Dupal signature in the genesis of the Jurassic Ferrar tholeiites from Prince Albert Mountains (Victoria Land, Antarctica), Contr. Mineral. Petrol., 136, 1-19.

Brotzu, P., G. Capaldi, L. Civetta, G. Orsi, G. Gallo and L. Melluso (1992), Geochronology and geochemistry of Ferrar rocks from North Victoria Land, Antarctica, Eur. J. Mineral., 4, 605-617.

Elliot, D. H. (2000), Stratigraphy of Jurassic pyroclastic rocks in the Transantarctic Mountains, J. African Earth Sci., 31, 77-89.

Elliot, D. H., M. A. Haban and M. A. Siders (1986), The Exposure Hill Formation, Mesa Range, - In Stump E. (ed.), Geological Investigations in Northern Victoria Land, AGU Antarctic Res. Series, 46, 267-278.

Elliot, D.H., T.H. Fleming, M.A. Haban and M.A. Siders (1995), Petrology and mineralogy of the Kirkpatrick Basalt and Ferrar Dolerite, Mesa Range Region, North Victoria Land, Antarctica, - In Elliot D.H., Blaisdell G.L. (eds.), Contributions to Antarctic Research IV, AGU Antarctic Res. Series, 67, 103-141.

Elliot, D.H. and R.E. Hanson (2001), Origin of widespread, exceptionally thick basaltic phreatomagmatic tuff breccia in the
Middle Jurassic Prebble and Mawson Formations, Antarctica, J. Volc. Geotherm. Res., 111, 183-201.

Fleming T.H., K.A. Foland and Elliot D.H. (1995) Isotopic and chemical constraints on the crustal evolution and source signature of Ferrar magmas. Contrib. Mineral. Petrol., 121, 217-236.

Grapes, R.H., D.L. Reid and J.G. McPherson (1973) Shallow dolerite intrusions and phreatic eruption in the Allan Hills region, Antarctica, New Zealand J. Geol. Geophys., 17, 563-577.

Hanemann R. and L. Viereck-Goette (2004) Geochemistry of Jurassic Ferrar flows, sills and dikes sampled during GANOVEX VIII. Terra Antartica, 11(1), 39-54.

Hanson, R.E. and D.H. Elliot (1996) Rift-related Jurassic basaltic phreatomagmatic volcanism in the central Transantarctic Mountains: precursory stage of flood-basalt effusion. Bull. Volcanol., 58, 327347.

Hergt, J.M., B.W. Chappell, G. Faure and T.M. Mensing (1989a), The geochemistry of Jurassic dolerites from Portal Peak, Antarctica, Contrib. Mineral. Petrol., 102, 298-305.

Hergt, J.M., B.W. Chappell, M.T. Mc Culloch, I. Mc Dougall and A.R. Chivas (1989b), Geochemical and Isotopic Constraints on the Origin of the Jurassic Dolerites of Tasmania, J. Petrol., 30, 841-883.

Kokelaar, B.P. (1982), Fluidization of wet sediments during the emplacement and cooling of various igneous bodies, J. Geol. Soc. London, 139, 21-33.

Korsch, R.J. (1984) The structure of Shapeless Mountain, Antarctica, and its relation to Jurassic igneous activity. New Zealand J. Geol. Geophys., 27, 487-504.

McClintock, M. and J.D.L. White (2006), Large phreatomagnetic vent complex at Coombs Hills, Antarctica: Wet, explosive initiation of flood basalt volcanism in the Ferrar-Karoo LIP, Bull. Volcanol., 68, 215-239.

Musumeci, G., P.C. Pertusati, C. Ribecai and M. Meccheri (2004) Early Jurassic Fossiliferous Black Shales in the Exposure Hill Formation, Ferrar Group of Northern Victoria Land, Antarctica. Terra Antarctica Reports, 12, 91-98.

Roland, N, and G. Woerner (1996), Kirkpatrick Flows and Associated Pyroclastics: New Occurrences, Definition, and Aspects of a Jurassic Transantarctic Rift. Geol.Jb., B89, 97-121.

Ross, P.S. and White, J.D.L. (2006), Debris jets in continental phreatomagmatic volcanoes: A field study of their subterranean deposits in the Coombs Hills vent complex, Antarctica., J. Volc. Geotherm. Res., 149, 62-84.

Schöner, R., L. Viereck-Goette, J. Schneider and B. Bomfleur (2007, this volume), Triassic-Jurassic sediments and multiple volcanic events in North Victoria Land, Antarctica: A revised stratigraphic model.

White, J.D.L. and M.K. McClintock (2001), Immense vent complex marks flood-basalt eruption in a wet, failed rift: Coombs Hills, Antarctica, Geology, 29, 935-938. 